\title{
Front Matter: Volume 8341
}

, "Front Matter: Volume 8341," Proc. SPIE 8341, Active and Passive Smart Structures and Integrated Systems 2012, 834101 (8 May 2012); doi: 10.1117/12.963996

SPIE Event: SPIE Smart Structures and Materials + Nondestructive Evaluation and SPIE. Health Monitoring, 2012, San Diego, California, United States 


\section{PROCEEDINGS OF SPIE}

\section{Active and Passive Smart Structures and Integrated Systems 2012}

Henry A. Sodano

Editor

12-15 March 2012

San Diego, California, United States

Sponsored by

SPIE

Cosponsored by

American Society of Mechanical Engineers (United States)

Cooperating Organizations

Intelligent Materials Forum (Japan)

Jet Propulsion Laboratory (United States)

National Science Foundation (United States)

Published by

SPIE

Volume 8341 
The papers included in this volume were part of the technical conference cited on the cover and title page. Papers were selected and subject to review by the editors and conference program committee. Some conference presentations may not be available for publication. The papers published in these proceedings reflect the work and thoughts of the authors and are published herein as submitted. The publisher is not responsible for the validity of the information or for any outcomes resulting from reliance thereon.

Please use the following format to cite material from this book:

Author(s), "Title of Paper," in Active and Passive Smart Structures and Integrated Systems 2012, edited by Henry A. Sodano, Proceedings of SPIE Vol. 8341 (SPIE, Bellingham, WA, 2012) Article CID Number.

ISSN 0277-786X

ISBN 9780819489982

Published by

SPIE

P.O. Box 10, Bellingham, Washington 98227-0010 USA

Telephone +1 3606763290 (Pacific Time) · Fax +1 3606471445

SPIE.org

Copyright (C) 2012, Society of Photo-Optical Instrumentation Engineers

Copying of material in this book for internal or personal use, or for the internal or personal use of specific clients, beyond the fair use provisions granted by the U.S. Copyright Law is authorized by SPIE subject to payment of copying fees. The Transactional Reporting Service base fee for this volume is $\$ 18.00$ per article (or portion thereof), which should be paid directly to the Copyright Clearance Center (CCC), 222 Rosewood Drive, Danvers, MA 01923. Payment may also be made electronically through CCC Online at copyright.com. Other copying for republication, resale, advertising or promotion, or any form of systematic or multiple reproduction of any material in this book is prohibited except with permission in writing from the publisher. The CCC fee code is 0277-786X/12/\$18.00.

Printed in the United States of America.

Publication of record for individual papers is online in the SPIE Digital Library.

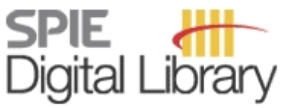

SPIEDigitalLibrary.org

Paper Numbering: Proceedings of SPIE follow an e-First publication model, with papers published first online and then in print and on CD-ROM. Papers are published as they are submitted and meet publication criteria. A unique, consistent, permanent citation identifier (CID) number is assigned to each article at the time of the first publication. Utilization of CIDs allows articles to be fully citable as soon as they are published online, and connects the same identifier to all online, print, and electronic versions of the publication. SPIE uses a six-digit CID article numbering system in which:

- The first four digits correspond to the SPIE volume number.

- The last two digits indicate publication order within the volume using a Base 36 numbering system employing both numerals and letters. These two-number sets start with 00, 01, 02, 03, 04, $05,06,07,08,09,0 A, 0 B \ldots 0 Z$, followed by 10-1Z, 20-2Z, etc.

The CID number appears on each page of the manuscript. The complete citation is used on the first page, and an abbreviated version on subsequent pages. Numbers in the index correspond to the last two digits of the six-digit CID number. 


\section{Contents}

xi Conference Committee

\section{SESSION 1 ENERGY HARVESTING AND SCAVENGING I: NONLINEAR ENERGY HARVESTING}

834102 Performance analysis of frequency up-converting energy harvesters for human locomotion [8341-01]

B. Anderson, A. Wickenheiser, The George Washington Univ. (United States)

834103 Harvestable vibrational energy from an avian source: theoretical predictions vs. measured values [8341-02]

M. W. Shafer, R. MacCurdy, E. Garcia, D. Winkler, Cornell Univ. (United States)

834104 Vibration energy harvesting using the nonlinear oscillations of a magnetostrictive material [8341-03]

E. Tsutsumi, Z. del Rosario, C. Lee, Franklin W. Olin College of Engineering (United States)

834105 A statistical linearization approach to optimal nonlinear energy harvesting [8341-04]

I. L. Cassidy, Duke Univ. (United States); J. T. Scruggs, Univ. of Michigan (United States)

\section{SESSION 2 PASSIVE AND ACTIVE VIBRATION ISOLATION I}

834106 New method of negative capacitance shunt tuning for vibration control [8341-06]

B. S. Beck, K. A. Cunefare, Georgia Institute of Technology (United States); M. Collet, FEMTO-ST, CNRS (France); M. Ruzzene, Georgia Institute of Technology (United States)

834107 Optimization of a passive piezoelectric damper for a viscously damped main system [8341-07]

S. M. Schwarzendahl, M. Neubaver, J. Wallaschek, Leibniz Univ. Hannover (Germany)

834108 Novel controller design demonstration for vibration alleviation of helicopter rotor blades [8341-08]

F. D. Ulker, National Research Council of Canada (Canada); F. Nitzsche, Carleton Univ. (Canada)

834109 Macro composites with non-classical inclusions for vibration damping in wind turbine [8341-09]

F. Agnese, F. Scarpa, Univ. of Bristol (United Kingdom)

$8341 \mathrm{OA}$ A bi-stable oscillator for increasing damping and providing passive adaptability [8341-05]

D. R. Johnson, M. Thota, Univ. of Michigan (United States); F. Semperlotti, Univ. of Notre

Dame (United States); K. W. Wang, Univ. of Michigan (United States) 
8341 OC Nonlinear dynamics of the bi-stable piezoelectric wind energy harvester [8341-11] M. A. Karami, Univ. of Michigan (United States); J. R. Farmer, Virginia Polytechnic Institute and State Univ. (United States); D. J. Inman, Univ. of Michigan (United States)

8341 OD Design and wind tunnel experimentation of a variable blade drag type vertical axis wind turbine [8341-12]

S. Mays, B. Bahr, California State Univ., Long Beach (United States)

$8341 \mathrm{OE} \quad$ Power and efficiency analysis of a flapping wing wind energy harvester [8341-13]

M. Bryant, M. W. Shafer, E. Garcia, Cornell Univ. (United States)

8341 OF A short investigation of the effect of an energy harvesting backpack on the human gait [8341-14]

E. Papatheou, P. Green, V. Racic, J. M. W. Brownjohn, N. D. Sims, The Univ. of Sheffield (United Kingdom)

8341 OG An evaluation on low-level vibration energy harvesting using piezoelectret foam [8341-69] S. R. Anton, K. M. Farinholt, Los Alamos National Lab. (United States)

\section{SESSION 4 BIOLOGICAL-INSPIRED SYSTEMS AND BIO-MEMS}

$8341 \mathrm{OH} \quad$ Fabrication and characterization of fluidic artificial muscles having millimeter-scale diameters [8341-15]

E. G. Hocking, N. M. Wereley, Univ. of Maryland, College Park (United States)

8341 ol Haptics using a smart material for eyes free interaction in mobile devices [8341-16] H. Wang, D. Kaleas, R. Ruuspakka, R. Tartz, Qualcomm Inc. (United States)

$8341 \mathrm{~J} \mathrm{Experiments} \mathrm{on} \mathrm{the} \mathrm{focusing} \mathrm{and} \mathrm{use} \mathrm{of} \mathrm{acoustic} \mathrm{energy} \mathrm{to} \mathrm{accelerate} \mathrm{polymer} \mathrm{healing}$ [8341-17]

A. J. Cushman, B. C. Fehrman, S. D. Gruenig, U. A. Korde, South Dakota School of Mines and Technology (United States)

\section{SESSION 5 OPTIMIZATION AND DESIGN OF INTEGRATED SYSTEMS I}

$8341 \mathrm{OL} \quad$ Uncertainty quantification of acoustic emission filtering techniques [8341-19]

B. A. Zárate, J. M. Caicedo, P. Ziehl, Univ. of South Carolina (United States)

8341 OM Optimal design of viscous damper connectors for adjacent structures using genetic algorithm and Nelder-Mead algorithm [8341-20]

K. Bigdeli, W. Hare, S. Tesfamariam, The Univ. of British Columbia (Canada)

8341 ON A modified command feedforward tracking control system applied to the PRRR-RR parallel mechanism [8341-21]

J. A. Parkins, J. F. O'Brien, Univ. of Wyoming (United States) 
834100 High shear rate characterization of magnetorheological fluids [8341-22]

A. C. Becnel, W. Hu, N. M. Wereley, Univ. of Maryland, College Park (United States)

8341 OP Realization of a MRF-safety-clutch for high torsional moments based on a novel ball-clutch design [8341-23]

M. Matthias, B. Seipel, M. Jackel, J. Kloepfer, Fraunhofer Institute Structural Durability and System Reliability (Germany)

$83410 Q \quad$ Feasibility study of self-powered magnetorheological damper systems [8341-24]

C. Chen, W.-H. Liao, The Chinese Univ. of Hong Kong (Hong Kong, China)

8341 OS Structural damping using encapsulated shear thickening fluids [8341-26]

M. Soutrenon, V. Michaud, Ecole Polytechnique Fédérale de Lausanne (Switzerland)

SESSION 7 ENERGY HARVESTING AND SCAVENGING III: GENERAL ENERGY HARVESTING I

8341 OT Investigating the energy harvesting potential of ferro-fluids sloshing in base-excited containers [8341-27]

A. Bibo, R. Masana, A. King, G. Li, M. F. Daqaq, Clemson Univ. (United States)

8341 OW Impedance optimization of wireless electromagnetic energy harvesters for maximum output efficiency at $\mu \mathrm{W}$ input power [8341-30]

A. Nimo, D. Grgić, L. M. Reindl, Albert-Ludwigs-Univ. of Freiburg (Germany)

8341 0X Multiple piezoelectric energy harvesters connected to different interface circuits [8341-31]

I. C. Lien, Y. C. Shu, National Taiwan Univ. (Taiwan)

8341 OY Electromagnetic vibration energy harvesting with high power density using a magnet array [8341-68]

X. Tang, T. Lin, L. Zuo, SUNY at Stony Brook (United States)

SESSION 8 AIRCRAFT, MAV/UAV, AND MORPHING SYSTEMS I

$83410 Z$ Steerable Adaptive Bullet (StAB) piezoelectric flight control system [8341-32]

R. Barrett, R. Barnhart, R. Bramlette, The Univ. of Kansas (United States)

SESSION 9 AIRCRAFT, MAV/UAV, AND MORPHING SYSTEMS II

834113 Material characterization for morphing purposes in order to match flight requirements [8341-37]

S. Geier, M. Kintscher, Deutsches Zentrum für Luft- und Raumfahrt e.V. (Germany);

O. Heintze, Invent GmbH (Germany); P. Wierach, H.-P. Monner, M. Wiedemann, Deutsches Zentrum für Luft- und Raumfahrt e.V. (Germany)

834114 Experimental characterization of simultaneous gust alleviation and energy harvesting for multifunctional wing spars [8341-102]

Y. Wang, D. J. Inman, Virginia Polytechnic Institute and State Univ. (United States) 
834115 Piezoelectric Low Net Passive Stiffness (LNPS) flutter test vane [8341-38]

R. Barnhart, R. M. Barrett, The Univ. of Kansas (United States)

834116 Mechanical and vibration testing of carbon fiber composite material with embedded piezoelectric sensors [8341-39]

K. P. Duffy, The Univ. of Toledo (United States) and NASA Glenn Research Ctr. (United States); B. A. Lerch, NASA Glenn Research Ctr. (United States); N. G. Wilmoth, ASRC Aerospace Corp. (United States) and NASA Glenn Research Ctr. (United States); N. Kray, G. Gemeinhardt, GE Aviation Systems (United States)

834117 Vibroacoustic studies on sounding rocket bulkheads [8341-40]

J. L. Comrie, U. A. Korde, South Dakota School of Mines and Technology (United States)

834119 Mathematical modelling of postbuckling in a slender beam column for active stabilisation control with respect to uncertainty [8341-42]

G. C. Enss, Technische Univ. Darmstadt (Germany); R. Platz, Fraunhofer Institute for Structural Durability and System Reliability (Germany); H. Hanselka, Technische Univ. Darmstadt (Germany) and Fraunhofer Institute for Structural Durability and System Reliability (Germany)

8341 1B Stabilization of a wide-band nonlinear vibration energy harvester by using a nonlinear self-excitation circuit [8341-44] A. Masuda, A. Senda, Kyoto Institute of Technology (Japan)

8341 1C Energy harvesting device for power generation onboard gravity-dropped weapons [8341-45]

J. Rastegar, R. Murray, Omnitek Partners, LLC (United States); M. Bridge, Air Force Research Lab. (United States)

8341 ID Improved pen harvester for powering a pulse rate sensor [8341-46] A. Marin, Virginia Polytechnic Institute and State Univ. (United States); P. Heitzmann, J. Twiefel, Virginia Polytechnic Institute and State Univ. (United States) and Leibniz Univ. Hannover (Germany); S. Priya, Virginia Polytechnic Institute and State Univ. (United States)

$8341 \mathrm{IE} \quad$ Modeling and experiment of a multiple-DOF piezoelectric energy harvester [8341-47] L. Tang, Y. Yang, H. Wu, Nanyang Technological Univ. (Singapore)

8341 IF Seismic fragility assessment of concrete bridge pier reinforced with shape memory alloy considering residual displacement [8341-48]

A. H. M. Muntasir Billah, M. Shahria Alam, The Univ. of British Columbia (Canada)

8341 1G On the optimization of piezoresistive plate-based sensors with distribution of piezoresistive material [8341-49]

L. A. M. Mello, E. C. N. Silva, Univ. of São Paulo (Brazil) 
$8341 \mathrm{lH} \quad$ Vibration reduction on a nonlinear flexible structure through resonant control and disturbance estimator [8341-50]

G. Cazzulani, F. Resta, F. Ripamonti, Politecnico di Milano (Italy)

83411 Control of structures featuring a new MRE isolator system [8341-51]

M. Behrooz, X. Wang, F. Gordaninejad, Univ. of Nevada, Reno (United States)

$83411 \mathrm{~J}$ Measurement of strain distribution in smart materials by electron Moiré method [8341-52] S. Kishimoto, National Institute for Materials Science (Japan); H. Asanuma, Chiba Univ. (Japan); Y. Tanaka, Y. Kagawa, National Institute for Materials Science (Japan)

SESSION 12A ENERGY HARVESTING AND SCAVENGING III: GENERAL ENERGY HARVESTING III

$8341 \mathrm{~K}$ The concurrent suppression of an energy harvesting from surface vibrations: experimental investigations [8341-53]

R. L. Harne, Virginia Polytechnic Institute and State Univ. (United States)

$83411 \mathrm{~L} \quad$ Multi-mechanism vibration harvester combining inductive and piezoelectric mechanisms [8341-54]

A. Marin, S. Priya, Virginia Polytechnic Institute and State Univ. (United States)

8341 IM Novel motion-doubling mechanism for improved piezoelectric energy-harvesting performance [8341-55]

J. Rastegar, R. Murray, Omnitek Partners, LLC (United States); C. Pereira, U.S. Army Armament

Research, Development and Engineering Ctr. (United States)

SESSION 12B SMA- AND PIEZO-BASED MATERIALS AND SYSTEMS I

834110 Multifunctional smart material system (MSMS) using shape memory alloys and shape memory polymers [8341-57]

P. Ghosh, A. Rao, A. R. Srinivasa, Texas A\&M Univ. (United States)

8341 1P Reducing vibration in carbon fiber structures with piezoelectric actuators and fiber Bragg grating sensors [8341-58]

G. Cazzulani, S. Cinquemani, L. Comolli, A. Gardella, Politecnico di Milano (Italy)

SESSION 13A MICRO AND NANO INTEGRATED SYSTEMS

$83411 \mathrm{~T} \quad$ Photo-responsible gel actuator developed with scanning microscopic light scattering [8341-62]

H. Furukawa, Yamagata Univ. (Japan); M. Yoshikawa, K. Yamada, T. Watanabe, Tokyo Univ. of Agriculture and Technology (Japan); R. Hidema, Yamagata Univ. (Japan); K. Horie, Japan Synchrotron Radiation Research Institute (Japan) 
8341 1U Power enhancement of piezoelectric transformers by adding thermal pad [8341-63]

Y. H. SU, Y. P. Liu, National Taiwan Univ. (Taiwan) and Ecole Normale Supérieure de Cachan (France); D. Vasic, Ecole Normale Supérieure de Cachan (France) and Univ. de Cergy-Pontoise (France); F. Costa, Ecole Normale Supérieure de Cachan (France) and Univ. Paris Est Créteil (France)

8341 IV Linear and non-linear systems identification for adaptive control in mechanical applications vibration suppression [8341-64]

G. Cazzulani, F. Resta, F. Ripamonti, Politecnico di Milano (Italy)

8341 IW Development of $d_{33}$-mode piezocomposite generating element [8341-65]

J. Zhao, Z. Xuan, N. S. Goo, Konkuk Univ. (Korea, Republic of)

SESSION 14A ENERGY HARVESTING AND SCAVENGING IV: DESIGN OF ENERGY HARVESTING SYSTEMS

$8341 \mathrm{IY}$ Multi-link piezoelectric structure for vibration energy harvesting [8341-67]

R. M. Aryanpur, R. D. White, Tufts Univ. (United States)

\section{SESSION 14B MAGNETO RHEOLOGICAL SYSTEMS II}

834120 Dynamic behavior of thick magnetorheological elastomers [8341-72]

N. Johnson, X. Wang, F. Gordaninejad, Univ. of Nevada, Reno (United States)

$834121 \quad$ MRF actuators with reduced no-load losses [8341-73]

D. Güth, J. Maas, Ostwestfalen-Lippe Univ. of Applied Sciences (Germany)

834122 A tunable 'negative' stiffness system for vibration control [8341-104]

Z. Li, Nanjing Univ. of Science \& Technology (China) and Nanjing Forestry Univ. (China);

X. Wang, M. Behrooz, N. Maus, F. Gordaninejad, Univ. of Nevada, Reno (United States)

834123 A bi-annular-gap magnetorheological energy absorber for shock and vibration mitigation [8341-75]

X.-X. Bai, Chongqing Univ. (China) and Univ. of Maryland, College Park (United States);

N. M. Wereley, Y.-T. Choi, Univ. of Maryland, College Park (United States); D.-H. Wang,

Chongqing Univ. (China)

\section{SESSION 15 PASSIVE AND ACTIVE VIBRATION ISOLATION II}

834125 Multiband damping of resonant vibrating piezoelastic structures by using digital adaptive passive shunting [8341-77]

H. Wernick, J. Korak, PROFACTOR GmbH (Austria)

834126 Integrated framework for jitter analysis combining disturbance, structure, vibration isolator and optical model [8341-78]

D.-O. Lee, J.-S. Yoon, J.-H. Han, KAIST (Korea, Republic of) 
834127 Development and performance study of a magnetic aerostatic vibration isolation platform [8341-80]

K.-N. Chang, K.-Y. Huang, National Taiwan Univ. (Taiwan)

\section{POSTER SESSION}

834129 Peeling stress analysis of piezo-bonded laminated composite plate [8341-84]

B. Huang, H. S. Kim, Dongguk Univ. (Korea, Republic of)

8341 2B Inter-crosslinking network gels having both shape memory and high ductility [8341-86] Y. Amano, R. Hidema, H. Furukawa, Yamagata Univ. (Japan)

$83412 \mathrm{C}$ Soft and wet actuator developed with responsible high-strength gels [8341-87] S. Harada, R. Hidema, H. Furukawa, Yamagata Univ. (Japan)

$83412 \mathrm{~F}$ Active vibration control of a submerged cylindrical shell by piezoelectric sensors and actuators [8341-90]

M. K. Kwak, D.-H. Yang, J.-H. Lee, Dongguk Univ. (Korea, Republic of)

$83412 \mathrm{H} \quad$ A novel method for piezoelectric energy harvesting from keyboard [8341-92]

L. Beker, A. Muhtaroğlu, H. Külah, Middle East Technical Univ. (Turkey)

$834121 \quad$ Maximizing PV module harvested output power using a computer-based automatic sun tracker [8341-93]

A. Abou-Elnour, A. Altamimi, T. Anajamrooz, O. Abo-Elnor, Ajman Univ. of Science \& Technology (United Arab Emirates)

$83412 \mathrm{~J}$ Dynamic control of beams acted by multiple moving masses in resonance state using piezo-ceramic actuators [8341-94]

M. Mofid, Sharif Univ. of Technology (Iran, Islamic Republic of); S. Eftekhar Azama, R. Afghani Khorasgani, Politecnico di Milano (Italy)

$83412 \mathrm{~K}$ Three-dimensional base-isolation system using thick rubber bearings [8341-96]

T. Wang, F. Wang, China Earthquake Administration (China)

$8341 \mathrm{~L} \quad$ Optimization of bond transducer vibrations using active and semiactive control [8341-97] M. Neubauer, Leibniz Univ. Hannover (Germany); M. Brökelmann, Hesse und Knipps GmbH (Germany); S. M. Schwarzendahl, Leibniz Univ. Hannover (Germany); H.-J. Hesse, Hesse und Knipps GmbH (Germany); J. Wallaschek, Leibniz Univ. Hannover (Germany)

$83412 \mathrm{M}$ Optimal vibration control of a rotating plate with self-sensing active constrained layer damping [8341-98]

Z. Xie, P. K. Wong, K. H. Lo, Univ. of Macau (Macao, China)

$83412 \mathrm{~N}$ Development of cantilevered energy harvesters coupled with a topologically optimized piezoelectric layer oscillating in vortex [8341-99]

C. Kim, J.-U. Shin, J.-Y. Kim, Kyungpook National Univ. (Korea, Republic of) 
$83412 \mathrm{Q}$ Optimization of piezoelectric bistable composite plates for broadband vibrational energy harvesting [834]-103]

D. N. Betts, H. A. Kim, C. R. Bowen, Univ. of Bath (United States); D. J. Inman, Univ. of Michigan (United States)

Author Index 


\title{
Conference Committee
}

\author{
Symposium Chairs
}

Norbert G. Meyendorf, Fraunhofer-Institut für Zerstörungsfreie

Prüfverfahren (Germany) and University of Dayton (United States)

Norman M. Wereley, University of Maryland, College Park

(United States)

Symposium Cochairs

Victor Giurgiutiu, University of South Carolina (United States)

Christopher S. Lynch, University of California, Los Angeles

(United States)

Conference Chair

Henry A. Sodano, University of Florida (United States)

Conference Cochairs

Wei-Hsin Liao, The Chinese University of Hong Kong

(Hong Kong, China)

Gyuhae Park, Los Alamos National Laboratory (United States)

Program Committee

Gregory S. Agnes, Jet Propulsion Laboratory (United States)

Mehdi Ahmadian, Virginia Polytechnic Institute and State University (United States)

Eric H. Anderson, CSA Engineering, Inc. (United States)

Hiroshi Asanuma, Chiba University (Japan)

Amr M. Baz, University of Maryland, College Park (United States)

Diann E. Brei, University of Michigan (United States)

Gregory P. Carman, University of California, Los Angeles (United States)

Aditi Chattopadhyay, Arizona State University (United States)

Seung-Bok Choi, Inha University (Korea, Republic of)

William W. Clark, University of Pittsburgh (United States)

Alison B. Flatau, University of Maryland, College Park (United States)

Farhan Gandhi, The Pennsylvania State University (United States)

Ephrahim Garcia, Cornell University (United States)

Mehrdad N. Ghasemi-Nejhad, University of Hawaili at Manoa (United States)

Victor Giurgiutiu, University of South Carolina (United States)

Fernando D. Goncalves, Lord Corporation (United States) 
Faramarz Gordaninejad, University of Nevada, Reno (United States)

Nakhiah C. Goulbourne, University of Michigan (United States)

Tristram Tupper Hyde, NASA Goddard Space Flight Center (United States)

Daniel J. Inman, Virginia Polytechnic Institute and State University (United States)

Conor D. Johnson, CSA Engineering, Inc. (United States)

Seung Jo Kim, Seoul National University (Korea, Republic of)

Yuji Matsuzaki, Nagoya University (Japan)

Roger Ohayon, Conservatoire National des Arts et Métiers (France)

Mohammad Rastgaar Aagaah, Massachusetts Institute of Technology (United States)

Norbert Schwesinger, Technische Universität München (Germany)

Steve Southward, Virginia Polytechnic Institute and State University (United States)

Roger Stanway, The University of Sheffield (United Kingdom)

Kon-Well Wang, University of Michigan (United States)

Norman M. Wereley, University of Maryland, College Park (United States)

\section{Session Chairs}

Energy Harvesting and Scavenging I: Nonlinear Energy Harvesting Henry A. Sodano, University of Florida (United States)

Passive and Active Vibration Isolation I

Ya D. Wang, Virginia Polytechnic Institute and State University (United States)

Energy Harvesting and Scavenging II: Fluid and Biological Energy Harvesting

Jeffrey T. Scruggs, University of Michigan (United States)

Biological-inspired Systems and Bio-MEMS

Alison B. Flatau, University of Maryland, College Park (United States)

Optimization and Design of Integrated Systems I

Kon-Well Wang, University of Michigan (United States)

Magneto Rheological Systems I

Norman M. Wereley, University of Maryland, College Park (United States)

Energy Harvesting and Scavenging III: General Energy Harvesting I Norbert Schwesinger, Technische Universität München (Germany) 
Aircraft, MAV/UAV, and Morphing Systems I

Matthew J. Brayant, Cornell University (United States)

Aircraft, MAV/UAV, and Morphing Systems II

Matthew J. Brayant, Cornell University (United States)

Energy Harvesting and Scavenging III: General Energy Harvesting II

Henry A. Sodano, University of Florida (United States)

Modeling, Simulation, Signal Processing, and Control of Integrated Systems II

Oliver J. Myers, Mississippi State University (United States)

Energy Harvesting and Scavenging III: General Energy Harvesting III Gyuhae Park, Los Alamos National Laboratory (United States)

SMA- and Piezo-based Materials and Systems I

Stuart G. Taylor, Los Alamos National Laboratory (United States)

Micro and Nano Integrated Systems

Wei-Hsin Liao, The Chinese University of Hong Kong (Hong Kong, China)

SMA- and Piezo-based Materials and Systems II

Gyuhae Park, Los Alamos National Laboratory (United States)

Energy Harvesting and Scavenging IV: Design of Energy Harvesting Systems

Wei-Hsin Liao, The Chinese University of Hong Kong (Hong Kong, China)

Magneto Rheological Systems II

Faramarz Gordaninejad, University of Nevada, Reno (United States)

Passive and Active Vibration Isolation II

Gyuhae Park, Los Alamos National Laboratory (United States) 
Downloaded From: https://www.spiedigitallibrary.org/conference-proceedings-of-spie on 26 Apr 2023

Terms of Use: https://www.spiedigitallibrary.org/terms-of-use 